\title{
Peningkatan Kemampuan Komunikasi Matematis: Pengembangan Lembar Kerja Siswa Berbasis Probing-Prompting untuk Siswa Sekolah Menengah Pertama
}

\author{
Nurul Fadhilah Syamsir ${ }^{1}$, Noviarni ${ }^{2}$ \\ 1,2 Program Studi Pendidikan Matematika, Universitas Islam Negeri Sultan Syarif Kasim Riau \\ Email: noviarni@uin-suska.ac.id
}

\begin{abstract}
ABSTRAK. Penelitian ini bertujuan untuk mendeskripsikan pengembangan lembar kerja siswa (LKS) matematika berbasis Probing-Prompting yang valid, praktis dan efektif untuk memfasilitasi kemampuan komunikasi matematis siswa pada materi aritmetika sosial. Jenis penelitian ini merupakan penelitian dan pengembangan dengan menggunakan model ADDIE (Analysis, Design, Development, Implementation, Evaluation). Penelitian ini dilakukan di SMP N 7 Dumai. Subjek penelitian adalah para ahli materi dan ahli media pembelajaran yang berasal dari kalangan dosen dan guru, serta siswa SMP N 7 Dumai. Objek penelitian adalah Lembar Kerja Siswa berbasis Probing-Prompting. Instrumen pengumpulan data berupa angket dan soal tes. Data yang diperoleh dianalisis dengan teknik analisis data kualitatif dan teknik analisis data kuantitatif. LKS yang dihasilkan pengembangan sudah teruji dengan tingkat kevalidan dan tingkat kepraktisannya. Selain itu, pengujian menunjukkan bahwa LKS tersebut dalam memfasilitasi kemampuan komunikasi. Oleh karena itu, LKS tersebut dapat digunakan untuk memfassilitasi kemampuan komunikasi matematis siswa.
\end{abstract}

Kata Kunci: Lembar Kerja Siswa, Probing-Prompting, Kemampuan Komunikasi Matematis, Sekolah Menengah Pertama.

\section{PENDAHULUAN}

Pendidikan merupakan suatu proses yang penting dalam kehidupan manusia untuk mempersiapkan dan melahirkan sumber daya manusia yang berkualitas serta unggul dalam semua dimensi agar mampu hidup di era globalisasi. Salah satu upaya pendidikan agar menghasilkan sumber daya manusia yang berkualitas adalah melalui pembelajaran matematika. Matematika merupakan salah satu ilmu dasar yang memiliki peran penting dalam kehidupan manusia, karena hampir semua ilmu pengetahuan dan teknologi memerlukan matematika. Seiring perkembangan zaman, ilmu matematika di tanah air sedang mengalami perubahan paradigma. Perubahan paradigma pendidikan matematika ditandai dengan adanya perubahan kurikulum untuk memperbaikan kurikulum sebelumnya. Seperti yang sedang diterapkan saat ini ialah kurikulum 2013 sebagai bentuk penyempurnaan dari kurikulum sebelumnya. Pada kurikulum 2013 diharapkan semua mata pelajaran harus ikut serta terhadap perkembangan siswa, tidak hanya cerdas dalam aspek kognitif (pengetahuan) saja namun juga pada aspek afektif (sikap) dan psikomotor (keterampilan). Pada mata pelajaran matematika siswa diharapkan terlibat secara aktif dan mengembangkan rasa ingin tau yang dimilikinya. Dalam matematika, komunikasi merupakan bagian yang sangat terpenting, karena tanpa adanya komunikasi maka matematika akan sulit untuk dikembangkan. Komunikasi matematis merupakan peristiwa yang terjadi di dalam 
lingkungan kelas yang berisi materi matematika yang di pelajari di kelas. Komunikasi yang dilakukan oleh guru dan siswa, bukan hanya proses pertukaran dan penyampaian materi, melainkan ada dimana guru dan siswa terjalin kedekatan yang baik dalam proses pembelajaran.

Pada pembelajaran matematika pada umumnya kebanyakan siswa masih bingung memahami soal yang ada, sehingga akan mengalami kesulitan dalam menyatakan ke dalam bentuk matematis. Kadang siswa mengalami kebingungan ketika harus membaca data yang tersaji dalam bentuk gambar, grafik, diagram atau simbol matematika lainnya. Jadi, dapat dikatakan kemampuan siswa dalam melakukan komunikasi matematika masih rendah.

Namun kenyataannya banyak siswa yang kesulitan dalam komunikasi matematis. Berdasarkan hasil observasi yang peneliti lakukan di SMP N 7 Dumai tepatnya di kelas VII pada tahun pelajaran 2017/2018, dapat disimpulkan bahwa komunikasi matematis siswa masih rendah. Hal ini dilihat pada aspek berikut:

1. Siswa hanya terfokus menjawab soal dengan melihat contoh soal yang diberikan

2. Siswa masih sulit dalam mengemukakan idea atau gagasan saat pembelajaran serta belum mampu mengkomunikasi ide matematika secara benar dalam bentuk soal cerita

3. Rendahnya hasil evaluasi siswa.

Berdasarkan gejala tersebut, perlu dilakukan perbaikan dan inovasi dalam proses pembelajaran matematika. Proses pembelajaran tidak terlepas dari komponen-komponen yang saling berinteraksi di dalamnya, salah satunya adalah bahan ajar. Bahan ajar merupakan bagian penting dalam pembelajaran, karena melalui bahan ajar guru akan lebih mudah dalam melaksanakan pembelajaran. Bahan ajar yang menarika dan inovatif merupakan hal yang sangat penting dan berkontribusi besar bagi proses pembelajaran yang dilaksanakan (Andi Prastowo, 2011, p. 23). Salah satu bentuk bahan ajar adalah Lembar Kerja Siswa (LKS)

Proses pembelajaran yang baik bergantung pada model pembeajaran yang dilakukan. Salah satu model pembelajaran yang diharapkan dapat meningkatkan kemampuan komunikasi matematis siswa adalah pembelajaran berbasis Probing-Prompting. Probing-Prompting yaitu pembelajaran dengan cara guru menyajikan serangkaian pertanyaan yang sifatnya menuntut dan menggali, sehingga terjadi proses berfikir yang mengaitkan pengetahuan sikap siswa dan pengalamannya dengan pengetahuan baru yang sedang di pelajari (Istarani dan Muhammad Ridwan, 2015, p. 111). Pembelajaran berbasis Probing-Prompting ini, siswa akan diberikan pertanyaan yang sederhana dan mudah dipahami sehingga siswa lebih aktif berfikir dan dapat mengembangkan keterampilan siswa dalam menjawab dan mengemukakan pendapatnya sendiri.

Berdasarkan penjelasan tersebut, peneliti akan mengembangkan Lembar Kerja Siswa berbasis Probing-Prompting. Pada LKS mencakup tahapan-tahapan dari Probing-Prompting. LKS berbasis Probing-Prompting diharapkan dapat meminimalkan peran guru, membuat siswa terlibat aktif dalam pembelajaran dan membantu siswa untuk mengkomunikasikan ide-idenya dalam mengerjakan soal, serta mempermudah siswa untuk memahami materi yang diberkan. LKS akan diracang sedemikian rupa sehingga dapat memenuhi kebutuhan siswa dalam meningkatkan kemampuan komunikasi matematisnya. Berdasarkan uraian yang telah disampaikan, penelitian ini bertujuan untuk menghasilkan LKS berbasis Probing-Prompting yang valid dan praktis dalam memfasilitasi kemampuan komunikasi matematis siswa SMP/ MTs Kelas VII semester 2

\section{TINJAUAN LITERATUR}

\section{Kemampuan Komunikasi Matematis}

Komunikasi merupakan suatu keterampilan yang sangat penting dalam kehidupan manusia dan merupakan suatu alat bagi manusia untuk berhubungan dengan orang lain di lingkungan baik secara verbal maupun tertulis (Hendriana Heris, dkk, 2017, p. 60). Dengan demikian, manusia memerlukan komunikasi dalam menjalankan kehidupan. 
Menurut Arni (2009) komunikasi adalah proses individu mengirim stimulus yang biasanya dalam bentuk verbal untuk mengubah tingkah laku orang lain. Matematika tidak hanya sekedar alat bantu berfikir, menemukan pola, menyelesaikan masalah, tetapi matematika sebagai wahana interaksi antar siswa serta sebagai alat komunikasi antara guru dan siswa.

Menurut Noraini Idris (2005), kemampuan komunikasi matematika adalah kemampuan dalam membaca, menafsirkan, menginterprestasikan grafik, dan menggunakan konsep matematika yang benar dalam menyampaikan argumen secara lisan maupun tulisan. Komunikasi matematis adalah suatu keterampilan penting dalam matematika, menurut The Intended Learning Outcomes yang dikutip oleh Purnama (2012), komunikasi matematis yaitu kemampuan untuk mengekspresikan ide-ide matematika secara koheren kepada teman, guru dan lainnya melalui bahasa lisan dan tulisan. Ini berarti dengan adanya komunikasi matematis, guru dapat lebih memahami kemampuan siswa dalam menginterprestasikan dan mengekspresikan pemahamannya tentang konsep yang mereka pelajari.

Kemampuan komunikasi matematis sebagai salah satu syarat untuk memecahkan masalah yang artinya, jika siswa tidak dapat berkomunikasi dengan baik dalam memaknai permasalahan dan konsep matematika maka ia tidak dapat menyelesaikan masalah tersebut dengan baik. Menurut NCTM, dalam belajar matematika peserta didik dituntut untuk memiliki kemampuan: problem solving (pemecahan masalah), reasoning and proof (pemahaman konsep), communication (komunikasi), connections (koneksi), representations (reprentasi). Kemampuan komunikasi matematis menunjang kemampuan-kemampuan matematis yang lain, misalnya kemampuan pemecahan masalah. Dengan kemampuan komunikasi yang baik maka suatu masalah akan lebih bisa dipresentasikan dengan benar dan hal ini akan mendukung untuk penyelesaian masalah (Henry Putra Imam Wijaya, 2009).

Berdasarkan berapa definisi berkaitan dengan komunikasi matematis yang di ungkapkan para ahli dapat ditarik kesimpulan bahwa komunikasi matematis adalah kemampuan siswa dalam menyampaikan sesuatu yang diketahuinya dalam bentuk benda nyata, gambar, tabel ke dalam bentuk matematika dengan menggunakan bahasa sendiri dengan menggunakan simbol matematika yang terjadi dilingkungan kelas.

Menurut Abdul Majid (2014) ada 5 komponen yang terlibat dalam komunikasi antara lain 1) Komunikator; 2) Pesan yang disampaikan; 3) Komunikan; 4) Konteks; 5) Sistem penyampaian. Sedangkan indikator kemampuan komunikasi menurut Nurahman (2011) adalah sebagai berikut 1) Menjelaskan ide atau situasi dari suatu gambar atau grafik engan kata-kata sendiri dalam bentuk tuisan (menulis); 2) Menyatakan suatu situasi dengan gambar atau grafik (menggambarkan); 3) Menyatakan suatu situasi ke dalam bentuk model matematika (ekspresi matematis)

Indikator kemampuan komunikasi menurut Cai Lane dan Jakobesin (2010) adalah 1) Kemampuan mengekspresikan ide matematis melalui lisan, tulisan serta mendemonstrasikan serta menggambarkan secara visual; 2) Kemampuan memahami, menginterprestasikan dan mengevaluasi ide matematis baik secara tulisan, lisan, maupun dalam bentuk visual lainnya; 3) Kemampuan dalam menggunakan istilah-istilah, notasi matematika dan struktur-strukturnya untuk menyajikan ide-ide, menggambarkan hubungan-hubungan dengan model-model situasi; 4) Berdasarkan penjelasan tersebut dapat ditarik kesimpulan bahwa kriterria komunnikasi matematis yang baik itu adalah apabila sudah memenuhi indikator yang telah dikemukakan diatas

\section{Teknik Probing-Prompting}

Menurut arti kata, probing adalah menyelidiki dan pemeriksaan, sementara prompting adalah mendorong atau menuntun. Probing question adalah "pertanyaan yang bersifat menggali untuk mendapatkan jawaban yang lebih lanjut dari siswa yang bermaksud mengembangkan kualitas jawaban, sehingga jawaban berikutnya lebih jelas, akurat serta lebih beralasan sedangkan prompting question, pertanyaan ini bermaksud untuk "menuntun siswa agar ia dapat menemukan jawaban yang lebih benar" (Suherman dkk, 2001, p. 160). Probing-Prompting pembelajaran dengan menyajikan serangkaian pertanyaan yang sifatnya menuntun dan menggali wawasan siswa 
sehingga dapat membenarkan proses berfikir yang mengaitkan pengetahuan dan pengalaman siswa dengan pengetahuan baru yang sedang dipelajari (Yuriska Mayasari, 2014).

Dari beberapa pernyataan dapat disimpulkan bahwa Probing-Prompting adalah pembelajaran yang menyajikan serangkaian pertanyaan yang sifatnya menuntun dan menggali sehingga terjadi proses berpikir yang mengaitkan pengetahuan siswa dan pengalamannya dengan pengetahuan baru yang sedang dipelajarinya sehingga siswa membangun sendiri pemahaman yang dimilikinya dan dapat diungkapkannya dalam bentuk komunikasi matematis.

Kelebihan pembelajaran Probing-Prompting (Istarani dan Muhammad Ridwan, 2015, p.112) yakni 1) Setiap siswa harus berpartisipasi aktif, karena ia harus siap-siap menunggu giliran untuk bertanya; 2) Siswa tidak bisa menghindar dari proses pembelajaran, karena siswa telah disiapkan pertanyaan oleh guru; 3) Setiap saat siswa bisa dilibatkan dalam proses Tanya jawab, karena siswa bisa saja ditanya tanggapannya tentang hasil jawabannya temannya. Sedangkan kekurangannya ialah 1) Membuat pertanyaan yang sesuai dengan kemampuan daya fikir siswa; 2) Kemungkinan akan terjadi suasana tegang, karena siswa takut diajukan pertanyaan kepadanya.

Langkah-langkah Probing-Prompting sebagai berikut 1) Siswa dihadapkan pada situasi baru, misalkan dengan memperhatikan gambar atau situasi lainnya yang mengandung pada permasalahan; 2) Guru mengajukan persoalan kepada siswa yang sesuai dengan tujuan pembelajaran atau indikator kepada seluruh siswa; 3) Menunggu beberapa saat untuk memberikan kesempatan kepada siswa untuk merumuskan jawaban atau melakukan diskusi kecil; 4) Menunjuk salah satu siswa untuk menjawab pertanyaan; 5) Jika jawabannya tepat maka guru meminta tanggapan kepada siswa lain tentang jawaban tersebut untuk meyakinkan bahwa seluruh siswa terlibat dalam kegiatan yang sedang berlangsung. Namun jika siswa tersebut mengalami kemacetan jawaban dalam hal ini jawaban yang diberikan kurang tepat, tidak tepat atau diam, maka guru mengajukan pertanyaan-pertanyaaan lain yang jawabannya merupakan petunjuk jalan penyelesaian jawaban; 6) Mengambil kesimpulan; 7) Guru mengajukan pertanyaan akhir pada siswa yang berbeda untuk lebih menekankan bahwa indikator tersebut benar-benar telah dipahami oleh seluruh siswa (Aris Shoimin, 2013).

Pada LKS pembelajaran berbasis Probing-Prompting yang muncul dalam LKS ada 5 tahap yakni (1) Siswa dihadapkan pada situasi baru, misalkan dengan memperhatikan gambar atau situasi lainnya yang mengandung permasalahan; (2) Siswa diberikan kesempatan untuk merumuskan jawaban; (3) enunjuk salah satu siswa untuk menjawab pertanyaan dan siswa lainnya memberikan tanggapan; (4) Siswa di minta membuat kesimpulan; (5) Mengajukan soal yang berbeda untuk lebih menekankan bahwa indikator telah dipahami oleh seluruh siswa.

\section{Lembar Kerja Siswa}

Menurut Hamdani, LKS merupakan perangkat pembelajaran sebagai pelengkap atau sarana pendukung pelaksanaan rencana pembelajaran. LKS merupakan lembaran kertas yang berupa informasi maupun soal soal (pertanyaan yang harus dijawab oleh siswa (2011, p.74-75). Sedangkan menurut Andi Prastowo materi ajar yang sudah dikemas sedemikian rupa, sehingga siswa diharapkan dapat mempelajari materi ajar tersebut secara mandiri (Andi Prastowo, 2011, p. 203). Jadi dapat disimpulkan Lembar kerja siswa adalah suatu bahan ajar cetak berupa lembarlembar kertas yang dapat membantu siswa dalam belajar, LKS terdiri dari ringkasan materi, cotoh soal latihan, dan petunjuk-petunjuk pelaksanaan tugas pembelajaran yang harus dikerjakan oleh peserta didik, yang mengacu pada kompetensi dasar yang harus dicapai.

\section{METODE}

Jenis penelitian yang digunakan adalah penelitian pengembangan. Penelitian pengembangan Research And Development (R\&D) adalah metode penelitian yang digunakan untuk menghasilkan produk tertentu dan menguji keefektifan produk tersebut (Sugiyono, 2016). Penelitian pengembangan ini dilakukan untuk menghasilkan produk yang dapat membantu dan 
mempermudah proses pembelajaran. Dari defenisi tersebut dapat disimpulkan bahwa tujuan utama dari R\&D adalah untuk menghasilkan atau menciptakan suatu produk. Produk yang dihasilkan dalam penelitian ini adalah LKS matematika berbasis Probing-Prompting yang valid dan praktis dalam memfasilitasi kemampuan komunikasi matematika siswa SMP/MTs Kelas VII Semester 2 pada materi aritmetika sosial. Model pengembangan yang digunakan adalah model ADDIE yang terdiri dari 5 tahap yaitu Analysis, Design, Development, Implementatin, dan Evaluation.

Subjek uji coba kelompok kecil adalah kelas VII. 6 yang di pilih sebanyak 6 siswa, sedangkan subjek uji coba kelompok besar adalah kelas VII. 1 yang berjumlah 30 siswa. Objek penelitian ini adalah LKS berbasis Probing-Prompting dan kemampuan komunikasi matematis siswa di kelas VII. 1 SMP Negeri 7 Dumai.

Jenis data pada penelitian ini adalah kualitatif dan kuantitatif. Data kualitatif didapat dari hasil vlidasi oleh validator serta dari angket praktikalitas siswa. Data kuantitatif didapat dari hasil tes kemampuan komunikasi matematis siswa.

Untuk mengetahui tingkat kevalidan dan kepraktisan LKS diukur dengan menggunakan angket dan untuk mengetahui tingkat efektifitas LKS yang dirancang menggunakan desain quasi experiment, yaitu the nonequivalent posttest-only control grup design. Pada desain ini terdapat dua kelompok, kelompok pertama diberi perlakuan (Eksperimen) dan kelompok lainnya tidak diberi perlakuan (kontrol). Gambaran desain ini dapat dilihat pada tabel berikut (Karunia Eka, 2017).

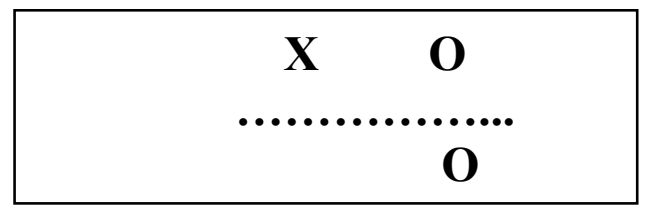

- X : Perlakuan/ treatment yang diberikan (berupa uji coba LKS) terhadap subjek uji coba

- O : Observasi setelah menggunakan LKS (berupa posttest)

\section{HASIL DAN PEMBAHASAN}

Pada penelitian ini menghasilkan LKS berbasis Probing-Prompting, yang dikembangkan dengan tahap-tahap sebagai berikut:

\section{Tahap Analysis}

Tahap analysis terbagi menjadi analisis kinerja dan analisis kebutuhan. Analisis kinerja dilakukan dengan merinci isi materi ajar dalam bentuk garis besar, yaitu mengacu pada Kurikulum 2013 khususnya materi aritmetika sosial untuk siswa SMP Kelas VII. Analisis kebutuhan untuk menentukan masalah dan solusi yaitu perlunya pengembangan LKS yang menarik minat siswa sehingga dapat meningkatkan prestasi belajarnya.

\section{Tahap Design}

Tahap Design merupakan tahapan untuk merancang LKS matematika berbasis Probing-Prompting serta komponen-komponen yang berkaitan dengan LKS tersebut. Bagian yang dirancang pada LKS adalah sebagai berikut: 
a. Cover
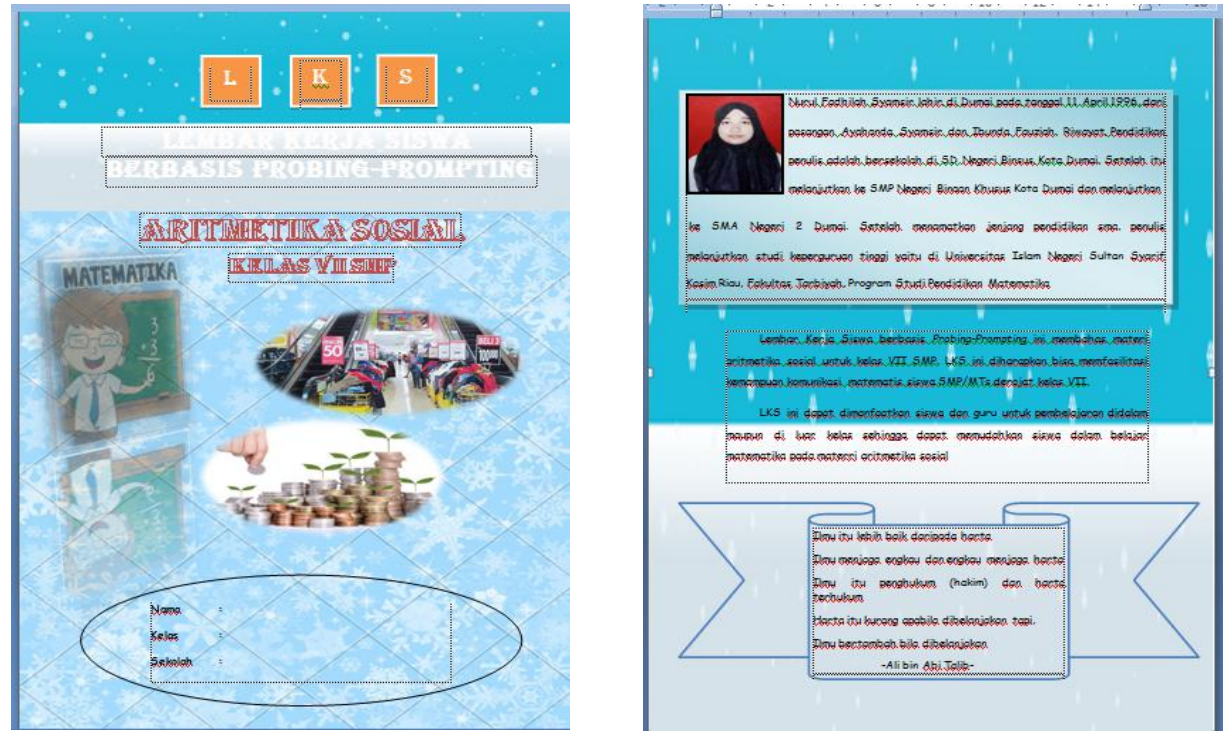

Gambar 1. Desain Cover LKS

b. Kata pengantar dan daftar isi

Kata pengantar berisi ucapan syukur kepada Allah SWT karena memenuhi kebutuhan siswa dalam proses pembelajaran. Sedangkan daftar isi memudahkan untuk mencari halaman LKS

c. Bagian pendabuluan

Pada bagian pendahuluan berisi tentang deskripsi singkat tentang LKS berbasis ProbingPrompting, petunjuk penggunaan LKS, standar kompetensi, kompetensi dasar, indikator dan tujuan pembelajaran.

\section{d. Peta konsep}

Peta konsep sangat penting bagi siswa maupun guru karena peta konsep menjadikan pembelajaran lebih terarah

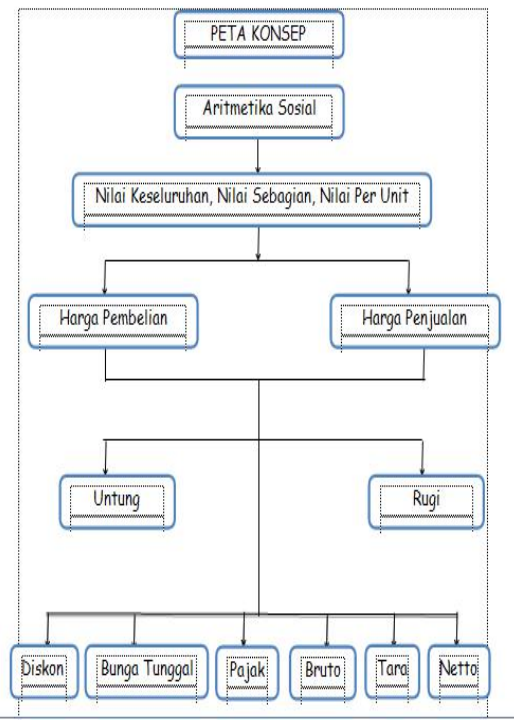

Gambar 2. Desain Peta Konsep 
e. Kegiatan belajar

Produk pengembangan LKS matematika berbasis Probing-Prompting terdapat kegiatan belajar yang disajikan dengan menarik dengan dimunculkannya pengantar sebuah wacana terlebih dahulu.

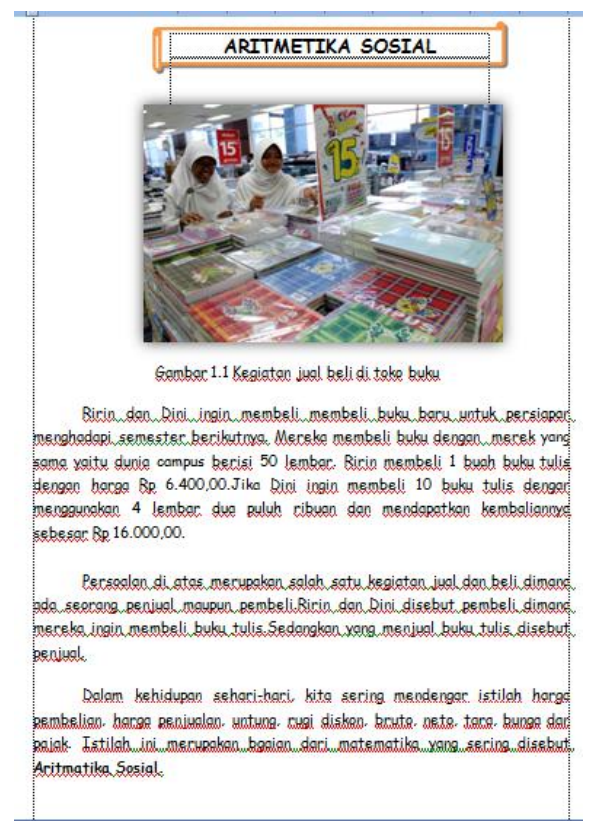

Gambar 3. Desain Kegiatan Belajar LKS

\section{Tahap Development}

Setelah tahap desain LKS selesai, kemudian LKS tersebut divalidasi oleh ahli materi dan ahli teknologi pendidilan dengan menggunakan angket .

a. Hasil Validasi LKS oleh Abli Teknologi Pendidikan

Tabel 1: Hasil Validasi Ahli Teknologi Pendidikan Terhadap LKS Matematika berbasis Probing-Prompting

\begin{tabular}{|c|l|c|c|}
\hline No & \multicolumn{1}{|c|}{ Kriteria LKS } & Nilai Validasi & Kriteria \\
\hline 1 & Penggunaan huruf dan tulisan & $83.75 \%$ & Sangat Valid \\
\hline 2 & Desain LKS & $80 \%$ & Valid \\
\hline 3 & Penggunaan gambar & $86.7 \%$ & Sangat Valid \\
\hline 4 & LKS berpenampilan menarik & $83.33 \%$ & Sangat Valid \\
\hline \multicolumn{2}{|c|}{ RATA-RATA } & $\mathbf{8 8 . 2 3 \%}$ & Sangat Valid \\
\hline
\end{tabular}

Berdasarkan Tabel 1, jelas terlihat bahwa persentase dari penilaian oleh dua ahli teknologi pendidikan adalah sangat valid, karena berada pada persentase keidealan $80 \% \leq$ Nilai $\leq 100 \%$, sehingga LKS pembelajaran tidak memerlukan revisi. Namun, komentar dan saran dari ahli teknologi pendidikan dijadikan bahan perbaikan untuk menyempurnakan LKS pebelajaran. 


\section{b. Hasil Validasi LKS oleh Abli Materi Peembelajaran}

Tabel 2: Hasil Validasi Ahli Materi Pembelajaran Terhadap LKS Matematika berbasis Probing-Prompting

\begin{tabular}{|c|c|c|c|c|c|}
\hline No & Tariabel Validitas & Indikator & $\begin{array}{c}\text { Nomor } \\
\text { pernyataan }\end{array}$ & Nilai validitas & Kriteria \\
\hline \multirow[t]{4}{*}{1} & \multirow[t]{4}{*}{ hat Didaktik } & A & $1,2,3$ & $90 \%$ & Sangat Valid \\
\hline & & $\mathrm{B}$ & $4,5,6$ & $84.47 \%$ & Sangat Valid \\
\hline & & $\mathrm{C}$ & $7,8,9$ & $90 \%$ & Sangat Valid \\
\hline & & $\mathrm{D}$ & $10,11,12$ & $93.33 \%$ & Sangat Valid \\
\hline \multirow[t]{2}{*}{2} & $\begin{array}{ll}\text { knik } & \text { Probing- } \\
\text { pmpting } & \end{array}$ & A & 13,14 & $83.35 \%$ & Sangat Valid \\
\hline & & B & $15,16,17$ & $82.23 \%$ & Sangat Valid \\
\hline \multirow[t]{4}{*}{3} & \multirow[t]{4}{*}{ Syarat Konstruksi } & A & $18,19,20$ & $93.33 \%$ & Sangat Valid \\
\hline & & $\mathrm{B}$ & $21,22,23$ & $86.7 \%$ & Sangat Valid \\
\hline & & $\mathrm{C}$ & 24,25 & $100 \%$ & Sangat Valid \\
\hline & & $\mathrm{D}$ & 26,27 & $86.7 \%$ & Sangat Valid \\
\hline \multicolumn{4}{|c|}{ RATA-RATA } & $87.65 \%$ & Sangat Valid \\
\hline
\end{tabular}

Berdasarkan Tabel 2, diketahui bahwa persentase keseluruhan aspek LKS dari penilaian kegiatan ahli materi pembelajaran adalah sangat valid karena berada pada persentase keidealan $80 \% \leq$ Nilai $\leq 100 \%$

c. Hasil Validasi LKS Keseluruban (Abli Teknologi Pendidikan dan Abli Materi Pembelajaran)

Tabel 3: Perhitungan Data Hasil Uji Validitas Secara Keseluruhan

\begin{tabular}{|c|l|c|}
\hline No & \multicolumn{1}{|c|}{ Variabel Validitas LKS } & Persentase Keseluruhan \\
\hline 1 & Ahli Materi Pembelajaran & $87.65 \%$ \\
\hline 2 & Ahli Teknologi Pendidikan & $88.23 \%$ \\
\hline \multicolumn{2}{|c|}{ RATA-RATA } & $\mathbf{8 7 . 9 4 \%}$ \\
\hline
\end{tabular}

Berdasarkan Tabel 3, diketahui bahwa persentase keseluruhan dari penilaian ahli teknologi pendidikan dan ahli materi pembelajaran adalah sangat valid karena berada pada persentase keidealan $80 \% \leq$ Nilai $\leq 100 \%$, sehingga LKS pembelajaran sudah layak untuk digunakan.

\section{Tahap Implementation}

Pada tahap implementasi ini, LKS diujicobakan kepada siswa SMP Negeri 7 Dumai. Uji coba yang dilakukan adalah uji coba kelompok kecil dilakukan kepada 6 siswa yang diambil dari kelas VII.6 SMP Negeri 7 Dumai dan uji coba lapangan dilakukan di kelas VII.1 SMP Negeri 7 Dumai yang berjumlah 30 siswa. Pada tahap ini diperoleh data kepraktisan dan keberhasilan penggunaan LKS untuk memfasilitasi kemampuan komunikasi matematis melalui angket dan tes 
a. Uji Coba Kelompok Kecil

Tabel 4: Hasil Uji Praktikalitas Kelompok Kecil Terhadap LKS Matematika berbasis Probing-Prompting

\begin{tabular}{|l|l|c|l|}
\hline No & \multicolumn{1}{|c|}{ Variabel Praktikalitas } & Nilai Praktikalitas & Kriteria \\
\hline 1 & Minat siswa dan tampilan LKS & $88.57 \%$ & Sangat Praktis \\
\hline 2 & Proses Penggunaan & $90.67 \%$ & Sangat Praktis \\
\hline 3 & $\begin{array}{l}\text { Teknik Probing-Prompting dan } \\
\text { kemampuan komunikasi } \\
\text { matematis }\end{array}$ & $91.67 \%$ & Sangat Praktis \\
\hline 4 & Waktu & $88.89 \%$ & Sangat Praktis \\
\hline 5 & Evaluasi & $88.89 \%$ & Sangat Praktis \\
\hline \multicolumn{2}{|l|}{ RATA-RATA } & & Sangat Praktis \\
\hline
\end{tabular}

Berdasarkan Tabel 4, perhitungan keseluruhan data hasil uji praktikalitas kelompok kecil adalah $89.86 \%$ sehingga dikategorikan sangat praktis karena berada pada persntase keidealan $80 \% \leq$ Nilai $\leq 100 \%$. Dari hasil tersebut maka LKS tidak memerlukan revisi lagi. Namun komentar dan saran dari siswa tetap dijadikan perbaikan untuk menyempurnakan LKS .

b. Uji Coba Lapangan

Tabel 5: Hasil Uji Praktikalitas Kelompok Besar Terhadap LKS Matematika berbasis Probing-Prompting

\begin{tabular}{|l|l|c|l|}
\hline No & \multicolumn{1}{|c|}{ Variabel Praktikalitas } & Nilai Praktikalitas & Kriteria \\
\hline 1 & Minat siswa dan tampilan LKS & $89.42 \%$ & Sangat Praktis \\
\hline 2 & Proses Penggunaan & $87.47 \%$ & Sangat Praktis \\
\hline 3 & $\begin{array}{l}\text { Teknik Probing-Prompting dan } \\
\text { kemampuan komunikasi } \\
\text { matematis }\end{array}$ & $88.11 \%$ & Sangat Praktis \\
\hline 4 & Waktu & $84.44 \%$ & Sangat Praktis \\
\hline 5 & Evaluasi & $\mathbf{8 6 . 5 3 \%}$ & Pangat Praktis \\
\hline \multicolumn{2}{|l|}{ RATA-RATA } & & \\
\hline
\end{tabular}

Berdasarkan Tabel 5, perhitungan keseluruhan data hasil uji praktikalitas kelompok besar adalah $86.53 \%$ sehingga dikategorikan sangat praktis karena berada pada persntase keidealan $80 \% \leq$ Nilai $\leq 100 \%$. Dari hasil tersebut maka LKS tidak memerlukan revisi lagi. Namun komentar dan saran dari siswa tetap dijadikan perbaikan untuk menyempurnakan LKS

\section{Tahap Evaluation}

Pada tahap evaluasi ini akan dibahas mengenai perbaikan dan saran-saran ahli materi pembelajaran dan teknologi pendidikan pada uji validitas dan siswa pada uji praktikalitas. Adapun saran tersebut sebagai berikut: 
Tabel 6: Saran Validator Terhadap LKS Matematika Berbasis Probing-Prompting

\begin{tabular}{|c|l|c|c|}
\hline No & \multicolumn{1}{|c|}{ Validator } & Saran & Perbaikan \\
\hline 1 & $\begin{array}{l}\text { Ahli Teknologi } \\
\text { Pendidikan I }\end{array}$ & $\begin{array}{c}\text { Perbaiki spasi judul dengan pengetikan materi, } \\
\text { Desain cover didesain ulang, konsistensi } \\
\text { penomoran, layout pengetikan perlu } \\
\text { diperbaiki }\end{array}$ & Sudah diperbaiki \\
\hline 2 & $\begin{array}{l}\text { Ahli Teknologi } \\
\text { Pendidikan II }\end{array}$ & $\begin{array}{c}\text { Perbaiki warna pada cover, gambar sesuai } \\
\text { dengan isi perintahnya, daftar referensi } \\
\text { ditambah lagi, setiap gambar harus disesuaikan } \\
\text { dengan materi dan harus mencantumkan } \\
\text { sumber }\end{array}$ & Sudah diperbaiki \\
\hline 3 & $\begin{array}{l}\text { Ahli Materi } \\
\text { Pendididikan I }\end{array}$ & $\begin{array}{r}\text { Buat pertanyaan lebih jelas, arahkan siswa } \\
\text { untuk menyelesaikan persoalan }\end{array}$ & Sudah diperbaiki \\
\hline 4 & $\begin{array}{l}\text { Ahli Materi } \\
\text { Pendidikan II }\end{array}$ & $\begin{array}{r}\text { Perbaiki penulisan kalimat, angka pada soal } \\
\text { harus real }\end{array}$ & Sudah diperbaiki \\
\hline 5 & $\begin{array}{l}\text { Ahli Materi } \\
\text { Pendidikan III }\end{array}$ & $\begin{array}{r}\text { Perbaiki tulisan, sesuaikan ilustrasi bacaan/ } \\
\text { gambar sesuai lingkungan sekolah }\end{array}$ & Sudah diperbaiki \\
\hline
\end{tabular}

LKS yang telah direvisi berdasarkan saran-saran dari para validator kemudian diujicobakan kepada kelompok kecil yang terdiri dari 6 siswa. Hal ini dilaukan untuk menguji apakah masih ditemukan kesalahan dan kekurangan pada LKS

\section{PEMBAHASAN}

Hasil analisis data validasi ahli teknologi pendidikan menunjukkan bahwa LKS berbasis ProbingPrompting yang dikembangkan berdasarkan syarat teknis mendapatkan kategori sangat valid dengan persentase keidealan $88.23 \%$. Hasil validasi yang dilakukan oleh ahli teknologi pendidikan pada setiap komponen sebagaimana dianalisis secara kuantitatif dapat dijelaskan sebagai berikut. 1) Penggunaan huruf dan tulisan pada LKS berbasis Probing-Prompting mendapat kategori sangat valid dengan persentase keidealan $83.75 \%$. 2) Desain LKS berbasis Probing-Prompting mendapat kategori valid dengan persentase keidealan 80\%. 3) Penggunaan gambar pada LKS berbasis ProbingPrompting mendapat kategori sangat valid dengan persentase keidealan 86.7\%. 4) Menurut ahli teknologi pendidikan, penampilan LKS berbasis Probing-Prompting sudah sangat valid dengan perentase keidealan $83.33 \%$. Hasil penilaian oleh ahli teknologi pendidikan tersebut menunjukkan LKS berbasis Probing-Prompting sudah sangat valid dan dapat digunakan dalam pembelajaran matematika.

Hasil analisis data validasi ahli materi pembelajaran menunjukkan bahwa LKS dengan berbasis Probing-Prompting yang dikembangkan mendapatkan kategori sangat valid dengan persentase keidealan $87.63 \%$. Hasil validasi yang dilakukan oleh ahli materi pembelajaran pada setiap komponen sebagaimana dianalisis secara kuantitatif dapat dijelaskan sebagai berikut. 1) Berdasarkan syarat didaktik bahwa LKS berbasis Probing-Prompting mendapat kategori sangat valid dengan persentase keidealan $88.89 \%$. 2) Berdasarkan syarat Probing-Prompting bahwa LKS berbasis Probing-Prompting mendapat kategori sangat valid dengan persentase keidealan $82.67 \%$. 3) Berdasarkan syarat konstruksi bahwa LKS berbasis Probing-Prompting mendapat kategori sangar valid dengan persentase keidealan $91.3 \%$. Hasil penilaian oleh ahli materi pembelajaran tersebut menunjukkan LKS berbasis Probing-Prompting sudah sangat valid dan dapat digunakan dalam pembelajaran matematika.

Hasil analisis data praktikalitas kelompok kecil menunjukkan bahwa LKS dengan berbasis Probing-Prompting yang dikembangkan mendapatkan kategori sangat praktis dengan persentase 
keidealan $89.86 \%$. Hasil penilaian ini ini menunjukkan LKS berbasis Probing-Prompting dinyatakkan sangat praktis oleh 6 siswa sehingga sudah bisa dijadikan bahan ajar dalam skala yang lebih besar.

Hasil analisis data praktikalitas kelompok besar menunjukkan bahwa LKS dengan berbasis Probing-Prompting yang dikembangkan mendapatkan kategori sangat praktis dengan persentase keidealan $86.53 \%$. Hasil penilaian ini ini menunjukkan LKS berbasis Probing-Prompting dinyatakkan sangat praktis oleh 30 siswa sehingga sudah bisa dijadikan bahan ajar.

Hasil efektifitas LKS yang diperoleh dari hasil tes soal komunikasi matematis yang diujikan pada kelas eksperimen dan kontrol dengan cara uji perbedaan menggunakan test-t taraf signifikan 5\% (setelah sebelumnya data hasil tes komunikasi matematis diuji normalitas dan homogenitasnya dan ternyata data tersebut normal dan juga homogen) diperoleh hasil yaitu

- Tabel 7: Uji T Skor Posttest

\begin{tabular}{|c|c|c|}
\hline $\mathbf{t}_{\text {hitung }}$ & $\mathbf{t}_{\text {tabel }}$ & Keterangan \\
\hline 2.83 & 2.01 & $\begin{array}{c}\text { Terdapat } \\
\text { perbedaan }\end{array}$ \\
\hline
\end{tabular}

Berdasarkan hasil penelitian telah dipeoleh $\mathbf{t}_{\text {hitung }}>\mathbf{t}_{\text {tabel }}$ maka terdapat perbedaan. Artinya terdapat perbedaan kemampuan komunikasi matematis antara kelas VII. 1 sebagai kelas eksperimen yang melakukan pembelajaran menggunakan LKS berbasis Probig-Prompting pada materi aritmetika sosial dan kelas VII.3 sebagai kelas kontrol yang merupakan pembelajaran konvensional.

Jadi dapat simpulkan bahwa LKS berbasis Probing-Prompting yang dikembangkan memiliki karakteristik valid dan praktis. Walupun telah terjadi peningkatan hasil belajar, tetapi hal ini belum lagi maksimal. Untuk itu peneliti menyarankan: (1) Bagi guru dapat menggunakan LKS matematika berbasis Probing-Prompting dalam proses pembelajaran materi aritmetika sosial karena telah diuji cobakan dan hasilnya valid, prakti serta dapat memfasilitasi kemampuan komunikasi matematis; (2) LKS matematika berbasis Probing-Prompting dikembangkan lebih lanjut dan mendalam dengan melakukan eksperimen menggunakan kelas pembanding agar kualitas LKS ini teruji keefektifannya; (3) Bagi peneliti selanjutnya hendaklah mengembangkan LKS matematika berbasis Probing-Prompting dengan materi berbeda dan pada materi yang lebih luas lagi.

\section{PENGHARGAAN}

Ucapan terima kasih kepada semua yang telah membantu dalam menyelesaikan penelitian ini.

\section{REFERENSI}

Hamdani. 2011. Strategi Belajar Mengajar, Bandung: Pustaka Setia

Heris Hendriana, Euis Eti Rohaeti dan Utari Sumarmo. 2017. Hard Skills dan Soft Skills Matematika Siswa. Bandung: Refika Aditama

Idris, Noraini. 2005. Pedagogi dalam Pendidikan Matematika. Selangor: Lahpron SDN

Istarani dan Muhammad Ridwan. 2015. 50 Tipe, Strategi dan Teknik Pembelajaran Kooperatif. Medan : CV. MEDIA PERSADA

Istarani \& Muhammad Ridwan. 2015. 50 Tipe Pembelajaran Kooperatif. Medan: CV. Media Persada

Jinfa Cai, dkk. 2010. Assesing Students' Mathematical Communication. School Science and Mathematics, 96(5), 238-246 
Karunia Eka Sari dan Mokhammad Ridwan. 2017. Penelitian Pendidikan Matematika. Bandung: Refika Aditama

Majid, Abdul. 2014. Strategi Pembelajaran Bandung: Remaja Rosdakarya

Mayasari, Yuriska. 2014. Jurnal Pendidikan Matematika Vol. 3 No. 1 : Penerapan Teknik ProbingPrompting Dalam Pembelajaran Matematika Siswa Kelas VIII MTSn Lubuk Buaya Padang, (Padang: FMIPA UNP)

Muhammad, Arni. 2009. Komunikasi Organisasi, Jakarta: Bumi Aksara

Nurahman. Pembelajaran Kooperatif Tipe Team-Accelerated Instruction (TAI) untuk Meningkatkan Kemampuan Penalaran dan Komunikasi Matematis Siswa SMP', Pasudan Journal of Mathematics Education, Vol. 1

Prastowo, Andi. 2011. Panduan Kreatif Membuat Bahan Ajar Inovatif, Jogjakarta: DIVA press

Ramellan, Purnama. dkk. 2012. Kemampuan komunikasi Matematis dan Pembelajaran Interaktif." Jurnal Pendidikan Matematika FMIPA UNP Vol. 1 No.1, Part 2

Shoimin, Aris. 2013. Model Pemebelajaran INOVATIF dalam Kurikulum 2013, Yogyakarta:AZRUZZ MEDIA

Sugiyono. 2016. Metode Penelitian Pendidikan Pendekatan, Kuantitatif, Kualitatif dan R\&D. Bandung : Alfabeta

Suherman dkk, 2001, Strategi Pembelajaran Matematika Kontemporer, Bandung: JICA UPI

Wijaya, Henry Putra Imam. 2016. Kemampuan Komunikasi Matematis Siswa Sesuai dengan Gender Dalam Pemecahan Masalah Pada Materi Balok Dan Kubus (Studi Kasus Pada Siswa SMP Kelas VIII SMP Islam Al-Azhar 29 Semarang) Jurnal Elektronik Pembelajaran Matematika Vol. 4 No. 9. ISSN: 2339-1685 